\title{
The Short-Term Influences of Covid-19 Pandemic on Indonesia Stock Exchange
}

\author{
Khairunnisa Nadhifah Syahfiraputri ${ }^{1}, \mathrm{Rr}$ Prasetiowati $^{2}, \mathrm{H} \mathrm{Hersugondo}^{3 *}$ \\ 1,3Department of Management, Faculty of Economics and Business, Universitas Diponegoro, \\ Indonesia \\ 2Department of Management, Sekolah Tinggi Ilmu Ekonomi Trisakti, Indonesia \\ *Corresponding Author: hersugondo@lecturer.undip.ac.id
}

\begin{abstract}
This study aimed to discern the short-term influences of the Covid-19 pandemic on the Indonesia Stock Exchange. The stocks from nine industries in Indonesia Stock Exchange were putting to use in this study. In this study, the short-term cumulative abnormal return was calculated by applying the data taken from 59 days of trading after the confirmation notice of the first Covid-19 case in Indonesia. The result of the study depicted a Return in the event window $(+1,+9)$ dropped drastically, which later bounced back; There was no cumulative abnormal return in the pre-event, and Cumulative abnormal return started to appear during event and post-event.
\end{abstract}

Keywords: Abnormal Return; Indonesia Stock Exchange; Short-Term Effect; Event Study; Industry Group; Covid-19 Announcement

\section{INTRODUCTION}

On December 31st, 2019, Wuhan Health Committee disclosed a case of "viral pneumonia" in Wuhan, Hubei Province, China. Subsequently, WHO requested an official statement from the government of China. They presented an official report about a case cluster finding of "viral pneumonia with unknown cause" in Wuhan on January 3rd, 2020.

On January 9th, 2020, the China government officially announced that the cause for this cluster case was Coronavirus. WHO immediately regulated this health case by publishing a package of comprehensive guidelines document from January $10^{\text {th }}$ to January $12^{\text {th }}, 2020$.

This virus rapidly spread to some countries outside China. 98 Covid-19 cases had been confirmed in 18 countries (without mortality) outside China on January 30th, 2020. In Germany, Japan, America, and Vietnam, eight human-to-human transmission cases were found. Responding to this situation, by the end of January 2020, WHO declared a public health emergency of international concern. 
This virus then continually spread to other countries that WHO officially declared that the Covid-19 case was a pandemic on March 11th, 2020, Figure 1. (https://www.who.int/news/item/29-06-2020-covidtimeline).

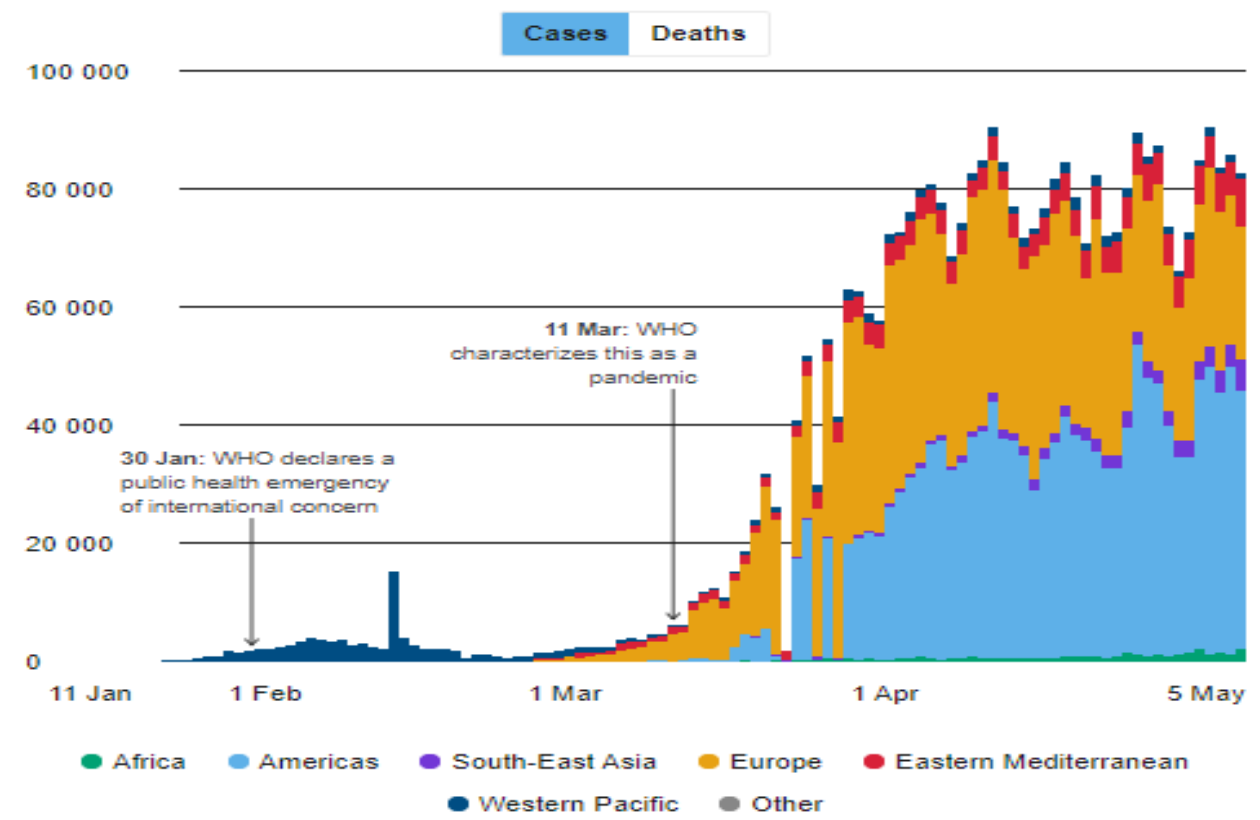

Figure 1. The Global Total of Covid-19 Case per May 5th, 2020

Source: https://www.who.int/data/gho/whs-2020-visual-summary

Data from WHO indicated that since it was first identified up to April 18 th, 2021, there have been $140,332,386$ cases in total globally, with a total of 3,004,088 mortality cases, Figure 2.

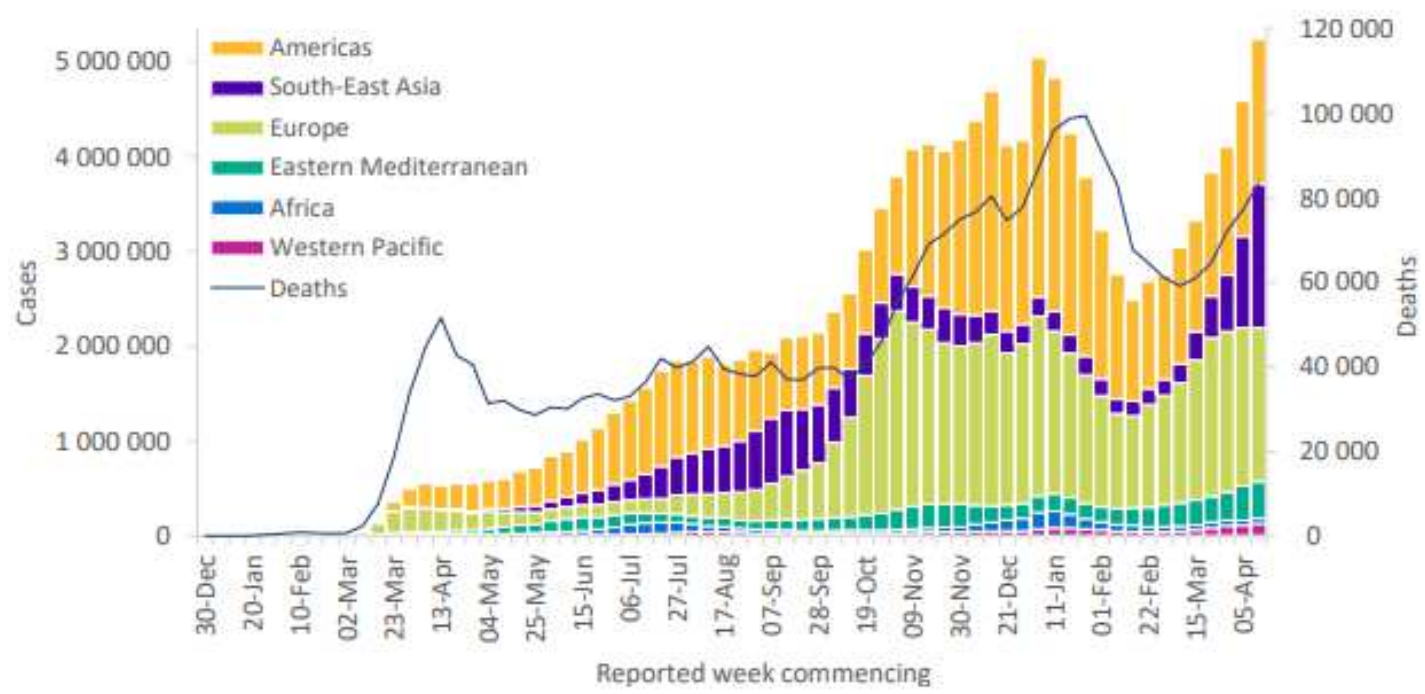

Figure 2. Weekly Total of Cases and Mortality following the Regions in the World per April $18^{\text {th }}$, 2021

Source: https://www.who.int/publications/m/item/weekly-epidemiological-update-on-covid-19---20-april2021 
In Indonesia itself, from January $22^{\text {th }}$ to $24^{\text {th }}, 2020$, Indonesia Health Office began to improve people's vigilance against the Covid-19 pandemic. On March 2nd, 2020, it confirmed the first positive Covid-19 case in Indonesia (https://corona.jakarta.go.id/en/artikel/linimasa-kebijakan-penanganan-pandemi-covid-19-di-jakarta).

Since then, up to April 18 ${ }^{\text {th }}, 2021$, there were 1,601,016 cases in total, out of which there were 105,859 cases of self-isolation, 1,455,065 recovered, and 43,424 death. This was reflected in Figure 3.

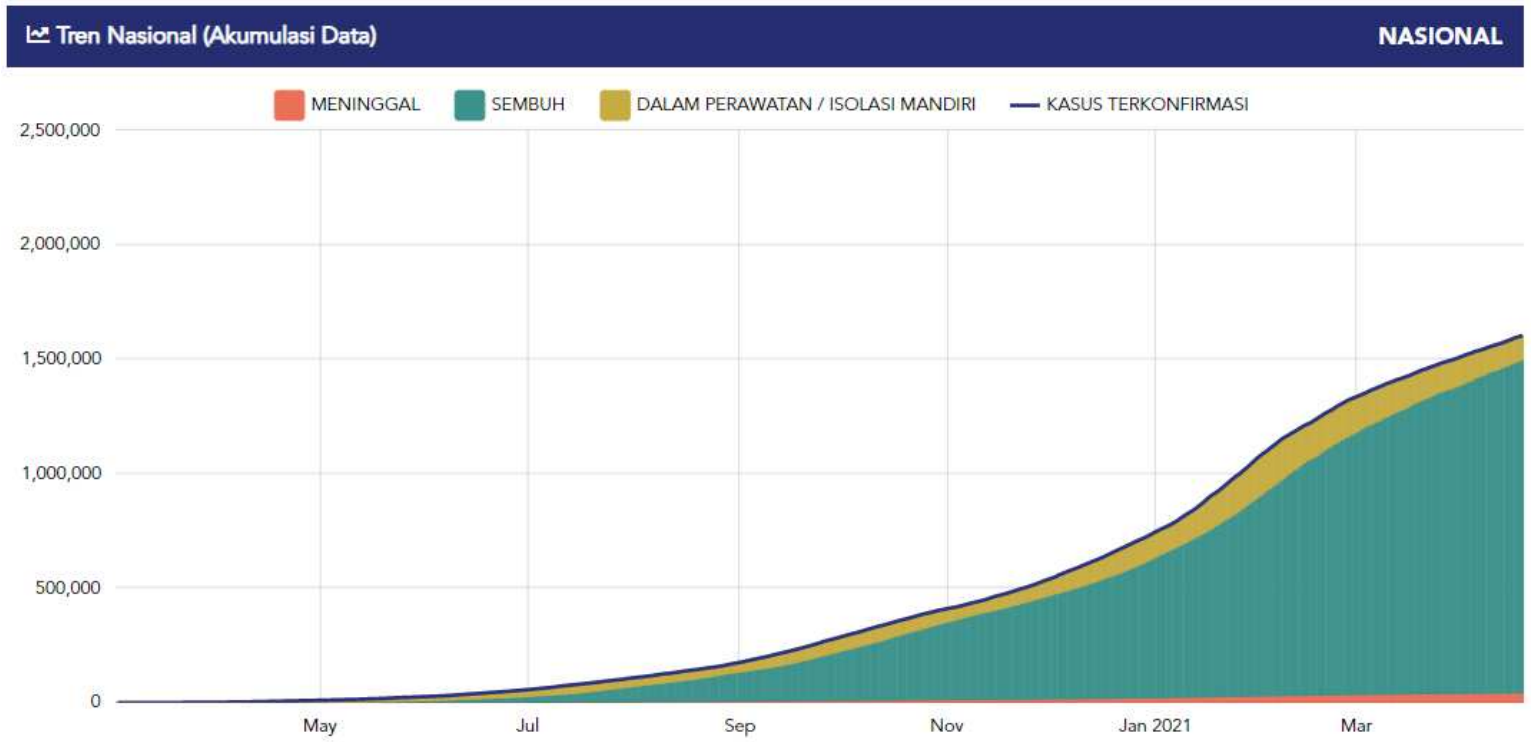

Figure 3. Total Covid-19 Cases of Confirmed, Recovered, and Death per April 18th, 2021 Source: https://covid19.go.id/peta-sebaran

The effect of this Covid-19 pandemic crippled the economy of most countries in the world. In China itself, its economy had been affected enough, reflected in a drop in Shanghai Stock Exchange since the beginning of January 2020. China's economy was predicted to grow only by $4,5 \%$, the lowest since 1992 . This number resulted from a manufacturing production halt in Wuhan, a crash in tourism, and a drop in the number of investors in China. This impacted other countries' economies, especially countries whose bilateral and multilateral trade agreements were with China, such as Indonesia (Nia, 2020).

Data per quarter II 2020 (YoY) indicated that the Southeast Asia economy experienced negative economic growth (Vietnam excluded), as reflected in Figure 4 infographic. Indonesia alone had the least negative economic growth compared to other countries in Southeast Asia, which was $-5,32 \%$ (YoY). (https://katadata.co.id/ariayudhistira/infografik/5f45ee727502e/covid-19-menjatuhkan-ekonomi-asiatenggara). 


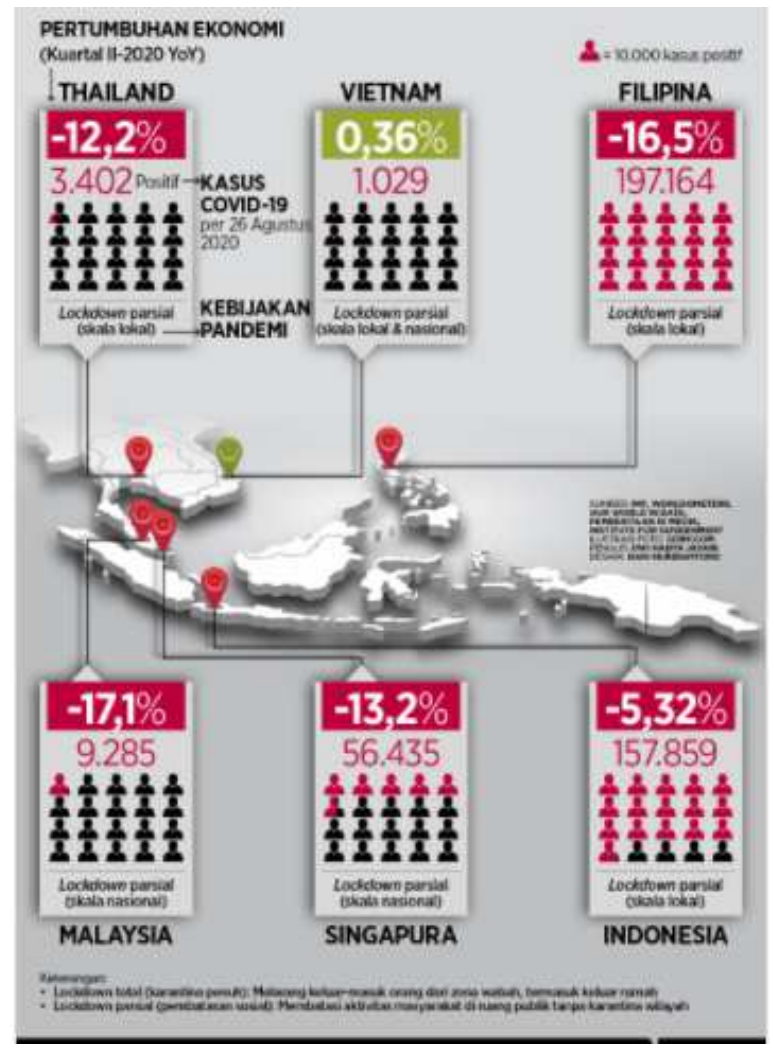

Figure 4. Economy Growth of Southeast Asia Quarter II-2020 (YoY)

Source: https:/ / katadata.co.id/ariayudhistira/infografik/5f45ee727502e/covid-19-menjatuhkan-ekonomiasia-tenggara

Previous studies related to the Covid-19 outbreak had been carried out through a method of event study to discern Covid-19 influences on 21 indices of the stock market in the most affected countries (Liu et al., 2020), on China and Asia stock market index (Liu et al., 2020), on G7 stock market index (Selmi \& Bouoiyour, 2020), and also on 21 industry indices in Arab Saudi stock market (Sayed \& Eledum, 2020). Another study was conducted by Hersugodo (2021) on Indonesia Stock Exchange to observe the reaction of the Indonesia Stock Exchange against the uncertainty brought about by the Covid-19 effect.

This study aimed to discern the short-term influences of Covid-19 on the Indonesia Stock Exchange, specifically on nine sectoral indices, by applying a method of an event study. The result of this study could be put to good use by the decision-makers and practitioners to manage investment risks relating to an investment portfolio and even other decisions, especially if it relates to each action of the industry sector. This study could be put to good use in making a profitable investment decision in this Covid-19 period for investors. Lastly, this study was expected to help other researchers to conduct the following related studies. 


\section{HYPOTHESIS DEVELOPMENT}

The Influences of Public Health Events on a Stock Market

Several previous studies depicted that there was a correlation of a public health event towards a stock market. Those studies were summarized in Table 1.

Table 1. The Studies on Influences of Public Health Events on a Stock Market

\begin{tabular}{|c|c|c|c|c|c|}
\hline No. & Reference & $\begin{array}{c}\text { Type of } \\
\text { Event }\end{array}$ & $\begin{array}{l}\text { Research } \\
\text { Sample }\end{array}$ & $\begin{array}{c}\text { Dependent } \\
\text { Variable }\end{array}$ & Finding \\
\hline 1. & $\begin{array}{l}\text { Wang et al. } \\
(2013)\end{array}$ & $\begin{array}{l}\text { Different } \\
\text { infectious } \\
\text { disease }\end{array}$ & $\begin{array}{l}38 \\
\text { registered } \\
\text { biotechnolo } \\
\text { gy } \\
\text { companies }\end{array}$ & $\begin{array}{l}\text { Biotechnolog } \\
\text { y stock } \\
\text { performance }\end{array}$ & $\begin{array}{l}\text { Significant abnormal return of } \\
\text { biotechnology stock due to } \\
\text { infectious epidemic. }\end{array}$ \\
\hline 2. & $\begin{array}{l}\text { Pendell \& } \\
\text { Cho (2013) }\end{array}$ & $\begin{array}{l}\text { Foot-and- } \\
\text { mouth } \\
\text { disease } \\
\text { (FMD) } \\
\text { outbreak }\end{array}$ & $\begin{array}{l}\text { Korea } \\
\text { agribusiness } \\
\text { companies }\end{array}$ & $\begin{array}{l}\text { A stock } \\
\text { market }\end{array}$ & $\begin{array}{l}\text { FMD outbreak caused a stock } \\
\text { market reacted both } \\
\text { negatively and positively. }\end{array}$ \\
\hline 3. & $\begin{array}{l}\text { Donadelli et } \\
\text { al. (2016) }\end{array}$ & $\begin{array}{l}\text { WHO } \\
\text { warning } \\
\text { about } \\
\text { dangerous } \\
\text { disease }\end{array}$ & $\begin{array}{l}\text { Pharmacy } \\
\text { companies } \\
\text { in USA }\end{array}$ & $\begin{array}{l}\text { Pharmacy } \\
\text { companies } \\
\text { stock in USA }\end{array}$ & $\begin{array}{l}\text { The effect was much more } \\
\text { impacting on small } \\
\text { companies since there was a } \\
\text { tiny chance for them to get } \\
\text { involved in a new vaccine } \\
\text { development. }\end{array}$ \\
\hline 4. & $\begin{array}{l}\text { Macchiocchi } \\
\text { et al. (2016) }\end{array}$ & $\begin{array}{l}\text { Zika virus } \\
\text { outbreak }\end{array}$ & $\begin{array}{l}\text { Brazil, } \\
\text { Argentina, } \\
\text { Mexico }\end{array}$ & $\begin{array}{l}\text { Stock market } \\
\text { indices in } \\
\text { Brazil, } \\
\text { Argentina } \\
\text { and Mexico }\end{array}$ & $\begin{array}{l}\text { Stock market indices had } \\
\text { negative return after the } \\
\text { warning. }\end{array}$ \\
\hline 5. & $\begin{array}{l}\text { Del \& } \\
\text { Paltrinieri } \\
(2017)\end{array}$ & $\begin{array}{l}\text { Ebola } \\
\text { outbreak } \\
\text { and the } \\
\text { Arab Spring }\end{array}$ & $\begin{array}{l}78 \text { equity } \\
\text { mutual } \\
\text { funds in } \\
\text { countries in } \\
\text { Africa }\end{array}$ & $\begin{array}{l}\text { Cash flow, } \\
\text { mutual fund } \\
\text { performance, } \\
\text { fund } \\
\text { withdrawal } \\
\text { by investors, } \\
\text { and stock } \\
\text { market return }\end{array}$ & $\begin{array}{l}\text { Ebola outbreak and the Arab } \\
\text { Spring affected cash flow, } \\
\text { mutual fund performance, } \\
\text { stock market return, and } \\
\text { triggered fund withdrawal by } \\
\text { investors. }\end{array}$ \\
\hline 6. & $\begin{array}{l}\text { Chen et al. } \\
\text { (2018) }\end{array}$ & $\begin{array}{l}\text { SARS } \\
\text { epidemic }\end{array}$ & $\begin{array}{l}\text { China stock } \\
\text { market and } \\
\text { four } \\
\text { countries in } \\
\text { Asia }\end{array}$ & $\begin{array}{l}\text { China stock } \\
\text { market } \\
\text { indices and } \\
\text { four countries } \\
\text { in Asia }\end{array}$ & $\begin{array}{l}\text { SARS epidemic weaken the } \\
\text { long-term relation between } \\
\text { stock markets in China and } \\
\text { four countries in Asia. }\end{array}$ \\
\hline 7. & $\begin{array}{l}\text { Liu et al. } \\
(2020)\end{array}$ & $\begin{array}{l}\text { Covid-19 } \\
\text { outbreak }\end{array}$ & $\begin{array}{l}\text { Stock } \\
\text { markets in } \\
\text { the most } \\
\text { affected } \\
\text { countries }\end{array}$ & $\begin{array}{l}21 \text { stock } \\
\text { market } \\
\text { indices in the } \\
\text { most affected } \\
\text { countries }\end{array}$ & $\begin{array}{l}\text { Stock market in the most } \\
\text { affected countries and in Asia } \\
\text { fell rapidly after Covid-19 } \\
\text { outbreak spread. }\end{array}$ \\
\hline 8. & $\begin{array}{l}\text { Liu et al. } \\
(2020)\end{array}$ & $\begin{array}{l}\text { Covid-19 } \\
\text { outbreak }\end{array}$ & $\begin{array}{l}\text { China and } \\
\text { Asia stock } \\
\text { markets }\end{array}$ & $\begin{array}{l}\text { China and } \\
\text { Asia stock } \\
\text { market } \\
\text { indices }\end{array}$ & $\begin{array}{l}\text { Cumulative abnormal return } \\
\text { indicated negative values } \\
\text { throughout all window } \\
\text { events. }\end{array}$ \\
\hline
\end{tabular}




\begin{tabular}{|c|c|c|c|c|c|}
\hline No. & Reference & $\begin{array}{l}\text { Type of } \\
\text { Event }\end{array}$ & $\begin{array}{l}\text { Research } \\
\text { Sample }\end{array}$ & $\begin{array}{c}\text { Dependent } \\
\text { Variable }\end{array}$ & Finding \\
\hline 9. & $\begin{array}{l}\text { Schell et al. } \\
(2020)\end{array}$ & $\begin{array}{l}\text { Public } \\
\text { health risk } \\
\text { emergency } \\
\text { which } \\
\text { becomes } \\
\text { global } \\
\text { attention }\end{array}$ & $\begin{array}{l}26 \text { world } \\
\text { stock } \\
\text { markets }\end{array}$ & $\begin{array}{l}26 \text { world } \\
\text { stock market } \\
\text { indices }\end{array}$ & $\begin{array}{l}\text { Market did not display } \\
\text { significant reaction which } \\
\text { meant economy impact from } \\
\text { several global scale diseases } \\
\text { relatively low, except for } \\
\text { Covid-19. }\end{array}$ \\
\hline 10. & $\begin{array}{l}\text { Selmi \& } \\
\text { Bouoiyour } \\
\text { (2020) }\end{array}$ & $\begin{array}{l}\text { Covid-19 } \\
\text { outbreak }\end{array}$ & $\begin{array}{l}\text { G7 } \\
\text { Countries } \\
\text { (Prancis, } \\
\text { Jerman, } \\
\text { Jepang, } \\
\text { Inggris, } \\
\text { Amerika, } \\
\text { Italia dan } \\
\text { Kanada) }\end{array}$ & $\begin{array}{l}\text { G7 countries } \\
\text { stock market } \\
\text { indices }\end{array}$ & $\begin{array}{l}\text { All stock markets in G7 } \\
\text { countries } \text { experienced } \\
\text { uncertainty due to Covid-19. } \\
\text { Goods and services flow were } \\
\text { going through disturbance. }\end{array}$ \\
\hline 11. & $\begin{array}{l}\text { Sayed \& } \\
\text { Eledum } \\
(2020)\end{array}$ & $\begin{array}{l}\text { Covid-19 } \\
\text { outbreak }\end{array}$ & $\begin{array}{l}\text { Arab Saudi } \\
\text { stock } \\
\text { market }\end{array}$ & $\begin{array}{l}21 \text { industry } \\
\text { indices in } \\
\text { Arab Saudi } \\
\text { stock market }\end{array}$ & $\begin{array}{l}\text { Cumulative abnormal return } \\
\text { from Arab Saudi stock market } \\
\text { was found insignificant when } \\
\text { the first case of Covid-19 was } \\
\text { announced in Arab Saudi. }\end{array}$ \\
\hline 12 & $\begin{array}{l}\text { Hersugondo } \\
\text { (2021) }\end{array}$ & $\begin{array}{l}\text { Covid-19 } \\
\text { outbreak }\end{array}$ & $\begin{array}{l}\text { Indonesia } \\
\text { Stock } \\
\text { Exchange }\end{array}$ & $\begin{array}{l}\text { Activity and } \\
\text { trading } \\
\text { volume in } \\
\text { Indonesia } \\
\text { Stock } \\
\text { Exchange }\end{array}$ & $\begin{array}{l}\text { Covid-19 outbreak had } \\
\text { positive and significant } \\
\text { influences on activity and } \\
\text { trading volume in Indonesia } \\
\text { Stock Exchange. }\end{array}$ \\
\hline
\end{tabular}

Based on conducted studies above, it indicated that public health condition influenced the stock market.

\section{Composite Stock Price Index (IHSG)}

A stock index is a statistic measurement reflecting the overall price movement of a collection of stock which is chosen based on certain criteria and methodology and is evaluated regularly. The purpose/benefit of the stock index is, among others, to calculate market sentiment, to serve as a benchmark for an active portfolio, to serve as a proxy in calculating and creating a return/systematic risk/performance model which is adjusted to risks.

Composite Stock Price Index (IHSG) is an index calculating the price performance of every stock recorded in the Main Board and Development Board of Indonesia Stock Exchange. This index was launched on April 4th , 1983, using April 1st, 1983, as the date basis and has the initial value of 100 (https://idx.co.id/produk/indeks/).

Economic condition, which is reflected by some macroeconomics indicators, highly influences the stock performance. Suppose the variable being observed is business beliefs to determine whether the economic condition is sound or adverse. In that case, it will be reflected in the stock exchange index of a country. There were statistically positive and significant relations of economic condition in Indonesia alone on Composite Stock Price Index, LQ45 Index, Jakarta Islamic Index, and Sectoral Index (Ayuningtyas \& 
Koesrindartoto, 2014). Therefore, Composite Stock Price Index (IHSG) may be used to describe the Indonesian stock market condition to describe an economic situation in Indonesia.

\section{Sectoral Index}

Sectoral Index in Indonesia Stock Exchange is divided into nine sectors which are explained in Table 2.

Table 2. Sectoral Index in Indonesia Stock Exchange

\begin{tabular}{cl}
\hline No. & Sectoral Index \\
\hline 1. & Farming Sector \\
2. & Mining Sector \\
3. & Basic and Chemical Industry Sector \\
4. & Various Industry Sector \\
5. & Consumer Goods Industry Sector \\
6. & Property Sector \\
7. & Infrastructure Sector \\
8. & Finance Sector \\
9. & Commerce Sector \\
\hline
\end{tabular}

Source: The Indonesia Capital Market Institute

According to Ayuningtyas \& Koesrindartoto's (2014) research, in Indonesia alone, there were statistically positive and significant relations of economic condition on Composite Stock Price Index, LQ45 Index, Jakarta Islamic Index, and also Sectoral Index. Therefore, the sectoral index can be served as a reference to describe Indonesia's economic condition and a stock market following each industry characteristic. Based on this description, then the hypothesis could be formulated as follows:

$\mathrm{H}_{1}$ : There was a cumulative abnormal return in each sectoral index after the Covid-19 announcement in Indonesia.

\section{METHOD, DATA, AND ANALYSIS}

An event study proposed by Ball and Brown (1968) aimed to evaluate the influence of an event over the change on the stock price. Fama, Fisher, Jensen, dan Roll (1969) introduced a method of event study to analyze the influence of emergency over the financial market. The effect of that condition is expected to reflect marketable securities price changes within a relatively short period after announcing that condition.

Delattre (2007) specifically summarized the implementation stages of an event study which covered event inventory, identification of announcement date, data removal, final sample selection, window event selection, model selection to determine abnormal return, calculation of influence on events in a stock market, and evaluation of research result significance.

According to MacKinlay (1997), the main task of an event study was defining things that one wanted to research and identifying an event window (assessment period). Furthermore, the estimation period or pre-event period must be determined as well. Figure 5 depicted that a pre-event window, an event window, and a post-event window which $t$ $=0$ was considered as the announcement date of a certain emergency, $T_{1+1}$ to $T_{2}$ represented 
an event window, and $T_{0+1}$ to $T_{1}$ was an estimation window or a pre-event, $T_{2+1}$ to $T_{3}$ showed a post-event.

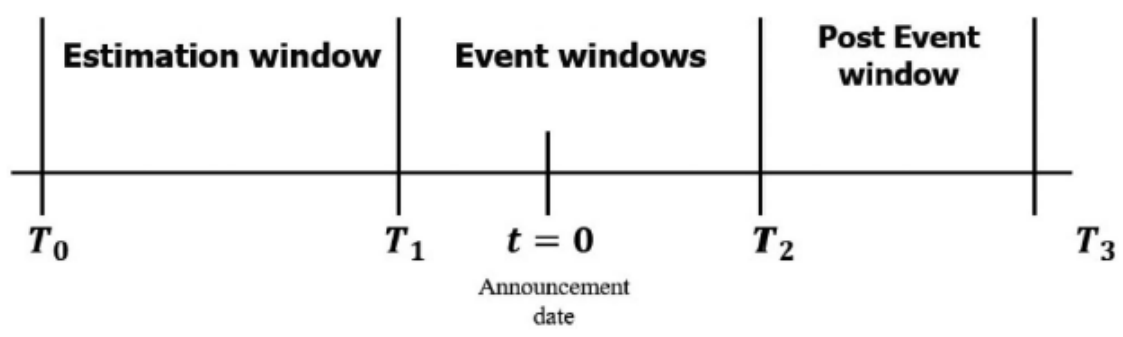

Figure 5. An Event Study Timeline Source: Sayed \& Eledum (2020)

\section{Estimation Model of Normal Return}

Normal return calculation was performed in the estimation period, which was essential to note that there would be a trade-off in selecting the estimation period. A higher precision level would be obtained by applying a longer period, but there would be a possibility that the data utilized might no longer be able for use.

Armitage (1995) stated that the average range of estimation period was [100, 300] for daily data and [24,60] for monthly data. MacKinlay (1997) suggested that 120 days prior to an event was suitable for a daily study.

Other than relating to the estimation period, MacKinlay (1997) stated that there were two models utilized to calculate the normal return, which was (1) constant mean return model that assumes the average return was constant; and (2) market model that assumed there was a stable linear relation between market return and marketable securities return.

Firstly, the Constant Mean Return model was the simplest model with a formula as following equation 1.

$$
R_{k, t}=\mu_{k}+u_{k, t}
$$

in which $\mu_{\mathrm{k}}$ was an average return for stock $\mathrm{k}$ and $u_{k, t}$ was random error for stock $\mathrm{k}$ in $\mathrm{t}$ time which was supposed to be distributed normally with 0 average and $\sigma_{k}^{2}$ variance as in $u_{k, t} \sim N\left(0, \sigma_{k}^{2}\right)$.

Secondly, Market Model was the most frequently used method which it calculated theoretical return as a linear function out of market index return. Based on this model, a stock return would be regressed against market index return with the formula in equation 2 .

$$
R_{k, t}=\alpha_{k}+\beta_{k} R_{m, t}+\varepsilon_{k, t}
$$

in which $\alpha_{k}$ and $\beta_{k}$ were regression equation parameters. $\varepsilon_{k, t}$ indicated statistical error with 0 average and constant variances, which were $\mathrm{E}\left(\varepsilon_{k, t}\right)=0$ and $\operatorname{Var}\left(\varepsilon_{\mathrm{k}, \mathrm{t}}\right)=\sigma_{k}^{2}$. 


\section{Estimation Model of Abnormal Return}

Abnormal return (AR) calculation was the difference between the observed return and expected return with no event (Sayed \& Eledum, 2020). Abnormal return for a group of industry of stock $k$ at that particular time $t\left(A R_{k, t}\right)$ was defined as equation 3 .

$$
A R_{k, t}=R_{k, t}-E\left(R_{k, t}\right)
$$

In which $E\left(R_{k, t}\right)$ was the expected return. The abnormal return formula above could be rewritten as following equation 4 .

$$
A R_{k, t}=R_{k, t}-\left(\hat{\alpha}_{k}+\hat{\beta}_{k} R_{m, t}\right)
$$

The cumulative abnormal return concept was required to accommodate several event windows. Cumulative abnormal return (CAR) from a sample within an event window $\left(t_{1}\right.$, $\mathrm{t}_{2}$ ) which $\mathrm{T} 1<\mathrm{t} 1 \leq \mathrm{t} 2<\mathrm{T} 2$ was the total of abnormal return within that event window. The formula used was as following equation 5 .

$$
C A R_{k,\left(t_{1}, t_{2}\right)}=\sum_{t=t_{1}}^{t_{2}} A R_{k, t}
$$

The average abnormal return for t-time was calculated as equation 6 , in which $n$ was the length of the window event.

$$
\overline{A R}_{k, t}=\frac{1}{n} \sum_{t=t_{1}}^{t_{2}} A R_{k, t}
$$

The abnormal return of a certain group of industries in a period did not tell many stories. Therefore it is advised to calculate the abnormal return average of all industry groups in a sample at $\mathrm{t}$ time for event window $\left(t_{1}, t_{2}\right)$ through a formula in equation 7.

$$
A A R M_{t,\left(t_{1}, t_{2}\right)}=\frac{1}{k} \sum_{j=1}^{k} A R_{j, t}
$$

Cumulative abnormal return from all industries (CAARM) could be calculated through a formula in equation 8 .

$$
C A A R M_{t}=\sum_{t=t_{1}}^{t_{2}} A A R M_{t}
$$

Describing CAARM into a graphic was going to help to visualize the influence of events and to assess whether that stock market was efficient or not.

In order to evaluate the significance out of the abnormal return, it applied a t-statistic parametric test (Wang et al., 2013; Pendell \& Cho, 2013; Donadelli et al., 2016; Liu et al., 2020; Liu et al., 2020; Schell et al., 2020; Selmi \& Bouoiyour, 2020; Sayed \& Eledum, 2020).

The distribution out of abnormal returns below $\mathrm{H}_{0}$ is shown in equation 9.

$$
A R_{t} \sim N\left(0, \sigma_{\varepsilon_{t}}^{2}\right)
$$

Therefore, for the group industry $(k)$, whether abnormal return $(A R)$ did not equal to zero could be evaluated by t-statistic as equation 10 .

$$
t \_s t a t=\frac{A R_{k, t}}{\widehat{\sigma}_{\varepsilon_{t}}^{2}}
$$

in which $\hat{\sigma}_{\varepsilon_{t}}^{2}$ was the deviation standard estimation out of abnormal return in the estimation period. The distribution of the cumulative abnormal return is as equation 11. 


$$
C A R_{k\left(t_{1}, t_{2}\right)} \sim N\left(0, \sigma_{k\left(t_{1}, t_{2}\right)}^{2}\right)
$$

Therefore, $t$-statistic could be formulated as equation 12, in which $\sigma_{k\left(t_{1}, t_{2}\right)}^{2}=n \sigma_{A R_{t}}^{2}$ and $\sigma_{A R_{t}}^{2}$ were a variance out of abnormal return average in one period.

$$
t \_s t a t=\frac{C A R_{k, t}}{\sqrt{n} \times \widehat{\sigma}_{A R_{t}}^{2}}
$$

In order to evaluate the short-term influences of the Covid-19 pandemic on nine sectoral indices in the Indonesia Stock Exchange, this study applied daily data of trading out of 431 shares in Indonesia Stock Exchange. The sample of this study was collected by a method of purposive sampling with criteria as follows:

1. The company was registered in a certain industry on Indonesia Stock Exchange.

2. The company actively performed trading within the research period.

Data were collected within the period of June 10th, 2019, to June 6th, 2020. These 431 shares were then categorized into nine industries as the ones in Indonesia Stock Exchange.

As a market index reference, it applied Composite Stock Price Index (IHSG) in the same period to calculate the abnormal return of nine sectoral indices. The data source originated from Indonesia Stock Exchange and The Indonesia Capital Market Institute (TICMI). The data processing used Excel and SPSS.

\section{Event Study Setting}

This study set March 2nd, 2020, as the main event date for that particular date the government of the Republic of Indonesia first announced/confirmed the presence of a Covid-19 case in Indonesia.

MacKinlay (1997) suggested that 120 days prior to the event was suitable for a daily study. The authors applied 165 trading days of daily data prior to the main event date to generate more accurate results.

In order to discern the Covid-19 pandemic in several different periods, the authors applied seven-event windows either before or prior to the main event date, as seen in Table 3.

Table 3. Event Window and the Basis in Determining Event Window

\begin{tabular}{cccccl}
\hline No & $\begin{array}{c}\text { Event } \\
\text { Window }\end{array}$ & Date & $\begin{array}{c}\text { Total of } \\
\text { Trading } \\
\text { Day }\end{array}$ & Remark & Event Window Determination \\
\hline 1. & $(-186,-21)$ & $\begin{array}{c}\text { 10 June } 2019 \\
-31 \text { January } \\
2020\end{array}$ & $\begin{array}{c}165 \text { trading } \\
\text { days }\end{array}$ & Pre-event & $\begin{array}{l}\text { Normal condition prior to } \\
\text { Covid-19 pandemic }\end{array}$ \\
\hline 2. & $(-20,-1)$ & $\begin{array}{c}3-28 \\
\text { February } \\
2020\end{array}$ & $\begin{array}{c}21 \text { trading } \\
\text { days }\end{array}$ & $\begin{array}{c}\text { During } \\
\text { event }\end{array}$ & $\begin{array}{l}\text { Cancellation of some sports, } \\
\text { cultural, and entertainment } \\
\text { events }\end{array}$ \\
\hline 3. & $(0)$ & 2 March 2020 & $\begin{array}{c}1 \text { trading } \\
\text { days }\end{array}$ & $\begin{array}{c}\text { During } \\
\text { event }\end{array}$ & $\begin{array}{l}\text { Main event date: } \\
\text { Announcement/confirmation of }\end{array}$ \\
\hline
\end{tabular}




\begin{tabular}{|c|c|c|c|c|c|}
\hline No & $\begin{array}{c}\text { Event } \\
\text { Window }\end{array}$ & Date & $\begin{array}{c}\text { Total of } \\
\text { Trading } \\
\text { Day }\end{array}$ & Remark & Event Window Determination \\
\hline & & & & & $\begin{array}{l}\text { the first Covid-19 case in } \\
\text { Indonesia. }\end{array}$ \\
\hline 4. & $(+1,+9)$ & $\begin{array}{c}\text { 3-15 March } \\
2020\end{array}$ & $\begin{array}{l}9 \text { trading } \\
\text { days }\end{array}$ & $\begin{array}{c}\text { During } \\
\text { event }\end{array}$ & $\begin{array}{l}\text { Statement from the Ministry of } \\
\text { Education and Culture of the } \\
\text { Republic of Indonesia to impose } \\
\text { stay-at-home order for schools, } \\
\text { universities. } \\
\text { Cancellation announced by the } \\
\text { government for many events and } \\
\text { celebrations, conferences, and } \\
\text { sports activities. }\end{array}$ \\
\hline 5. & $(+10,+20)$ & $\begin{array}{c}16-31 \\
\text { March } 2020\end{array}$ & $\begin{array}{l}11 \text { trading } \\
\text { days }\end{array}$ & $\begin{array}{l}\text { During } \\
\text { event }\end{array}$ & $\begin{array}{l}\text { Enforcement of Big Scale Social } \\
\text { Restriction (PSBB) order in } \\
\text { accordance with Minister of } \\
\text { Health Order No. } 9 \text { Year } 2020 .\end{array}$ \\
\hline 6. & $(+21,+53)$ & $\begin{array}{l}1 \text { April - } \\
27 \text { May } 2020\end{array}$ & $\begin{array}{l}33 \text { trading } \\
\text { days }\end{array}$ & Post-event & $\begin{array}{l}\text { Implementation of new normal } \\
\text { scenario by considering regional } \\
\text { promptness and the result of } \\
\text { epidemiology research in related } \\
\text { areas. }\end{array}$ \\
\hline 7. & $(+54,+59)$ & $\begin{array}{l}28 \text { May - } \\
6 \text { June } 2020\end{array}$ & $\begin{array}{l}6 \text { trading } \\
\text { days }\end{array}$ & Post-event & $\begin{array}{l}\text { The enforcement of } \\
\text { Commencement for Criteria and } \\
\text { Traveling Requirements in } \\
\text { accordance with a Circular Letter } \\
\text { No. } 7 \text { the Year } 2020 \text {. }\end{array}$ \\
\hline
\end{tabular}

\section{RESULT}

After every data was successfully collected, thus a daily return of every industry started to be calculated by applying a formula as equation 13 .

$$
R_{k, t}=\frac{\left(P_{k, t}-P_{k, t-1}\right)}{P_{k, t-1}}
$$

and daily return of Composite Stock Price Index was calculated by applying a formula as equation 14 .

$$
R_{m, t}=\frac{\left(P_{m, t}-P_{m, t-1}\right)}{P_{m, t-1}}
$$

In which $R_{k, t}$ and $R_{m, t}$ represented the return of industry $k$ and market at $t$-time. $P_{k, t}$ dan $P_{m, t}$ represented the closing price of industry $k$ and market at $t$-time. The last was $P_{k, t-1}$ dan $\mathrm{P}_{\mathrm{m}, \mathrm{t}-\mathrm{1}}$ represented the closing price of industry $\mathrm{k}$ and market in the previous day of trading. 
The description for the average and deviation standard of the nine industries in Indonesia Stock Exchange prior to and after main event date, can be seen in table 4 .

Table 4. The Average and Standard of Industry Deviation in each Window Event

\begin{tabular}{|c|c|c|c|c|c|c|c|c|c|c|c|c|}
\hline \multirow{3}{*}{ INDUSTRY } & \multirow{2}{*}{\multicolumn{2}{|c|}{$\begin{array}{l}\text { Pre-event } \\
(-186 .-21)\end{array}$}} & \multicolumn{6}{|c|}{ During event } & \multicolumn{4}{|c|}{ Post-event } \\
\hline & & & \multicolumn{2}{|c|}{$(-20,-1)$} & \multicolumn{2}{|c|}{$(+1,+9)$} & \multicolumn{2}{|c|}{$(+10,+20)$} & \multicolumn{2}{|c|}{$(+21,+53)$} & \multicolumn{2}{|c|}{$(+54,+59)$} \\
\hline & Avg & Dev Std & Avg & Dev Std & Avg & Dev Std & Avg & Dev Std & Avg & Dev Std & Avg & Dev Std \\
\hline \multirow[t]{2}{*}{ Farming } & & & & & & & & & & & & \\
\hline & -0.00017 & 0.01192 & -0.00689 & 0.01854 & -0.01682 & 0.03397 & -0.00409 & 0.04545 & 0.00120 & 0.01793 & 0.00734 & 0.01328 \\
\hline \multirow[t]{2}{*}{ Mining } & & & & & & & & & & & & \\
\hline & -0.00088 & 0.01209 & -0.00233 & 0.01092 & -0.01174 & 0.03064 & 0.00082 & 0.03431 & 0.00158 & 0.01487 & 0.00434 & 0.01291 \\
\hline \multirow{3}{*}{$\begin{array}{l}\text { Basic and } \\
\text { Chemical } \\
\text { Industry }\end{array}$} & & & & & & & & & & & & \\
\hline & & & & & & & & & & & & \\
\hline & 0.00093 & 0.01264 & -0.00765 & 0.01692 & -0.01802 & 0.04240 & -0.00602 & 0.05621 & 0.00622 & 0.03018 & 0.01070 & 0.01498 \\
\hline \multicolumn{13}{|l|}{ Various } \\
\hline Industry & 0.00040 & 0.01970 & -0.00679 & 0.01234 & -0.00835 & 0.03511 & -0.00430 & 0.06062 & 0.00380 & 0.02037 & 0.00550 & 0.00805 \\
\hline \multicolumn{13}{|l|}{ Consumer } \\
\hline \multicolumn{13}{|l|}{ Goods } \\
\hline Industry & -0.00121 & 0.00988 & -0.00645 & 0.01115 & -0.00097 & 0.03218 & -0.00061 & 0.06666 & 0.00289 & 0.01976 & -0.00060 & 0.00751 \\
\hline \multicolumn{13}{|l|}{ Property } \\
\hline & -0.00019 & 0.00964 & -0.00271 & 0.00908 & -0.01621 & 0.02744 & -0.00581 & 0.03512 & -0.00135 & 0.02247 & 0.01409 & 0.01386 \\
\hline \multicolumn{13}{|l|}{ Infrastructure } \\
\hline & -0.00067 & 0.01044 & -0.00432 & 0.01004 & -0.00751 & 0.03804 & -0.00605 & 0.05698 & 0.00257 & 0.02455 & 0.00654 & 0.01270 \\
\hline
\end{tabular}




\begin{tabular}{|c|c|c|c|c|c|c|c|c|c|c|c|c|}
\hline \multirow[t]{2}{*}{ INDUSTRY } & \multicolumn{2}{|c|}{$\begin{array}{l}\text { Pre-event } \\
(-186 .-21)\end{array}$} & \multicolumn{2}{|c|}{$(-20,-1)$} & \multicolumn{2}{|c|}{$\begin{array}{c}\text { During event } \\
(+1,+9)\end{array}$} & \multicolumn{2}{|c|}{$(+10,+20)$} & \multicolumn{4}{|c|}{${ }_{(+21,+53)}^{\text {Post-event }}(+54,+59)$} \\
\hline & Avg & Dev Std & Avg & Dev Std & Avg & Dev Std & Avg & Dev Std & Avg & Dev Std & Avg & Dev Std \\
\hline Finance & 0.00021 & 0.00789 & -0.00255 & 0.01093 & -0.00854 & 0.03509 & -0.00941 & 0.05679 & -0.00207 & 0.02139 & 0.02060 & 0.01717 \\
\hline Commerce & -0.00064 & 0.00574 & -0.00366 & 0.00627 & -0.01014 & 0.02033 & -0.00046 & 0.02822 & -0.00009 & 0.01161 & 0.00452 & 0.00714 \\
\hline
\end{tabular}

Furthermore, every data was swept away from the outliers and tested for its abnormality firsthand before performing Cumulative Abnormal Return (CAR) calculation. Table 5 below depicted Cumulative Abnormal Return (CAR) from every industry in Indonesia Stock Exchange in each window event.

Table 5. Cumulative Abnormal Return (CAR) Industry in Each Window Event

\begin{tabular}{|c|c|c|c|c|c|c|c|c|c|c|c|c|}
\hline \multirow{3}{*}{ INDUSTRY } & \multirow{2}{*}{\multicolumn{2}{|c|}{$\begin{array}{l}\text { Pre-event } \\
(-186 .-21)\end{array}$}} & \multirow{2}{*}{\multicolumn{4}{|c|}{$\begin{array}{c}\text { During event } \\
\quad(+1,+9)\end{array}$}} & \multirow{2}{*}{\multicolumn{2}{|c|}{$(+10,+20)$}} & \multicolumn{4}{|c|}{ Post-event } \\
\hline & & & & & & & & & \multicolumn{2}{|c|}{$(+21,+53)$} & \multicolumn{2}{|c|}{$(+54,+59)$} \\
\hline & CAR & T-stat & CAR & T-stat & CAR & T-stat & CAR & T-stat & CAR & T-stat & CAR & T-stat \\
\hline \multirow[t]{2}{*}{ Farming } & \multirow{2}{*}{$-0,03233$} & -0.252 & \multirow{2}{*}{$-0,12429$} & -1.587 & \multirow{2}{*}{$-0,13803$} & $-1,577$ & \multirow{2}{*}{$-0,03459$} & -0.274 & \multirow{2}{*}{0,03783} & 0.391 & \multirow{2}{*}{0,03373} & 1,080 \\
\hline & & $(0,802)$ & & $(0,129)$ & & $(0,154)$ & & $(0,789)$ & & $(0,698)$ & & $(0,329)$ \\
\hline \multirow[t]{2}{*}{ Mining } & \multirow{2}{*}{$-0,16223$} & -1.219 & \multirow{2}{*}{$-0,02665$} & -0.679 & \multirow{2}{*}{$-0,08500$} & -1.257 & \multirow{2}{*}{0,02496} & 0.317 & \multirow{2}{*}{0,04521} & 0.644 & \multirow{2}{*}{0,00897} & 0.323 \\
\hline & & $(0,225)$ & & $(0,506)$ & & $(0,244)$ & & $(0,758)$ & & $(0,524)$ & & $(0,760)$ \\
\hline \multirow{2}{*}{$\begin{array}{l}\text { Basic and } \\
\text { Chemical } \\
\text { Industry }\end{array}$} & \multirow[b]{2}{*}{0,01471} & 0.1 & \multirow[b]{2}{*}{$-0,10517$} & -1.513 & \multirow[b]{2}{*}{$-0,09279$} & -0.687 & \multirow[b]{2}{*}{$-0,00747$} & -0.035 & \multirow[b]{2}{*}{0,14305} & 0.704 & \multirow[b]{2}{*}{0,01146} & 0.297 \\
\hline & & $(0,920)$ & & $(0,147)$ & & $(0,512)$ & & $(0,972)$ & & $(0,486)$ & & 0,778 \\
\hline \multirow{2}{*}{$\begin{array}{l}\text { Various } \\
\text { Industry }\end{array}$} & \multirow{2}{*}{$-0,19921$} & -1.546 & \multirow{2}{*}{$-0,06761$} & -2.749 & \multirow{2}{*}{0,00308} & 0.172 & \multirow{2}{*}{$-0,02213$} & -2.020 & \multirow{2}{*}{0,06951} & 1.233 & & -3.607 \\
\hline & & $(0,124)$ & & $(0,013)^{* *}$ & & $(0,868)$ & & $(0,090)^{* * *}$ & & $(0,226)$ & 0,04024 & $(0,015)^{* *}$ \\
\hline
\end{tabular}


Jurnal Keuangan dan Perbankan

\begin{tabular}{|c|c|c|c|c|c|c|c|c|c|c|c|c|}
\hline \multirow{3}{*}{ INDUSTRY } & \multirow{2}{*}{\multicolumn{2}{|c|}{$\begin{array}{l}\text { Pre-event } \\
(-186 .-21)\end{array}$}} & \multicolumn{6}{|c|}{ During event } & \multicolumn{4}{|c|}{ Post-event } \\
\hline & & & \multicolumn{2}{|c|}{$(-20,-1)$} & \multicolumn{2}{|c|}{$(+1,+9)$} & \multicolumn{2}{|c|}{$(+10,+20)$} & \multicolumn{2}{|c|}{$(+21,+53)$} & \multicolumn{2}{|c|}{$(+54,+59)$} \\
\hline & CAR & T-stat & CAR & T-stat & CAR & T-stat & CAR & T-stat & CAR & T-stat & CAR & T-stat \\
\hline \multirow{2}{*}{$\begin{array}{l}\text { Consumer } \\
\text { Goods } \\
\text { Industry }\end{array}$} & \multirow[b]{2}{*}{0,03936} & 0.504 & \multirow[b]{2}{*}{$-0,00358$} & -0.362 & \multirow[b]{2}{*}{0,08478} & 3.111 & \multirow[b]{2}{*}{$-0,02007$} & -1.650 & \multirow[b]{2}{*}{0,10862} & 1.435 & \multirow[b]{2}{*}{$\begin{array}{c}- \\
0,06282\end{array}$} & -4.846 \\
\hline & & $(0,615)$ & & $(0,722)$ & & $(0,014)^{* *}$ & & $(0,174)$ & & $(0,160)$ & & $(0,005)^{*}$ \\
\hline \multirow[t]{2}{*}{ Property } & \multirow{2}{*}{$-0,01560$} & -0.151 & \multirow{2}{*}{0,01400} & 0.376 & \multirow{2}{*}{$-0,06629$} & -0.584 & \multirow{2}{*}{0,00670} & 0.058 & \multirow{2}{*}{$-0,09040$} & -0.543 & \multirow{2}{*}{0,04548} & 0.969 \\
\hline & & $(0,880)$ & & $(0,711)$ & & $(0,575)$ & & $(0,955)$ & & $(0,591)$ & & $(0,370)$ \\
\hline \multirow[t]{2}{*}{ Infrastructure } & \multirow{2}{*}{$-0,04901$} & -0.569 & \multirow{2}{*}{0,01211} & 0.355 & \multirow{2}{*}{0,02985} & 0.875 & \multirow{2}{*}{ 0,00990 } & 0.184 & \multirow{2}{*}{0,05813} & 0.788 & \multirow{2}{*}{$\begin{array}{c}- \\
0,01302\end{array}$} & -3.041 \\
\hline & & $(0,570)$ & & $(0,726)$ & & $(0,407)$ & & $(0,858)$ & & $(0,436)$ & & $(0,056)^{\star * *}$ \\
\hline \multirow{2}{*}{ Finance } & \multirow{2}{*}{$-0,07526$} & -1.537 & \multirow{2}{*}{0,01672} & 1.034 & \multirow{2}{*}{$-0,00206$} & -0.143 & \multirow{2}{*}{$-0,04874$} & -0.948 & \multirow{2}{*}{$-0,13503$} & -2.202 & 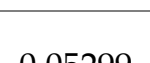 & 2.534 \\
\hline & & $(0,126)$ & & $(0,315)$ & & $(0,890)$ & & $(0,366)$ & & $(0,035)^{* *}$ & 0,05299 & $(0,052)^{* * *}$ \\
\hline Commerce & & -1.361 & & -1.361 & & -2.930 & & 0.654 & & -0.469 & - & -0.569 \\
\hline & $-0,07749$ & $(0,175)$ & $-0,02832$ & $(0,204)$ & $-0,04682$ & $(0,019)^{* *}$ & 0,02982 & $(0,528)$ & $-0,01775$ & $(0,642)$ & 0,00714 & $(0,594)$ \\
\hline
\end{tabular}


Figure 6 portrayed changes from cumulative average return (CAARM) in each event window. CAARM exhibited a drastic value drop in the event window $(+1,+9)$. This result was consistent with what was portrayed in Table 5 above. However, after that event window, it appeared there was again a rise in CAARM value up to the event window $(+21,+53)$.

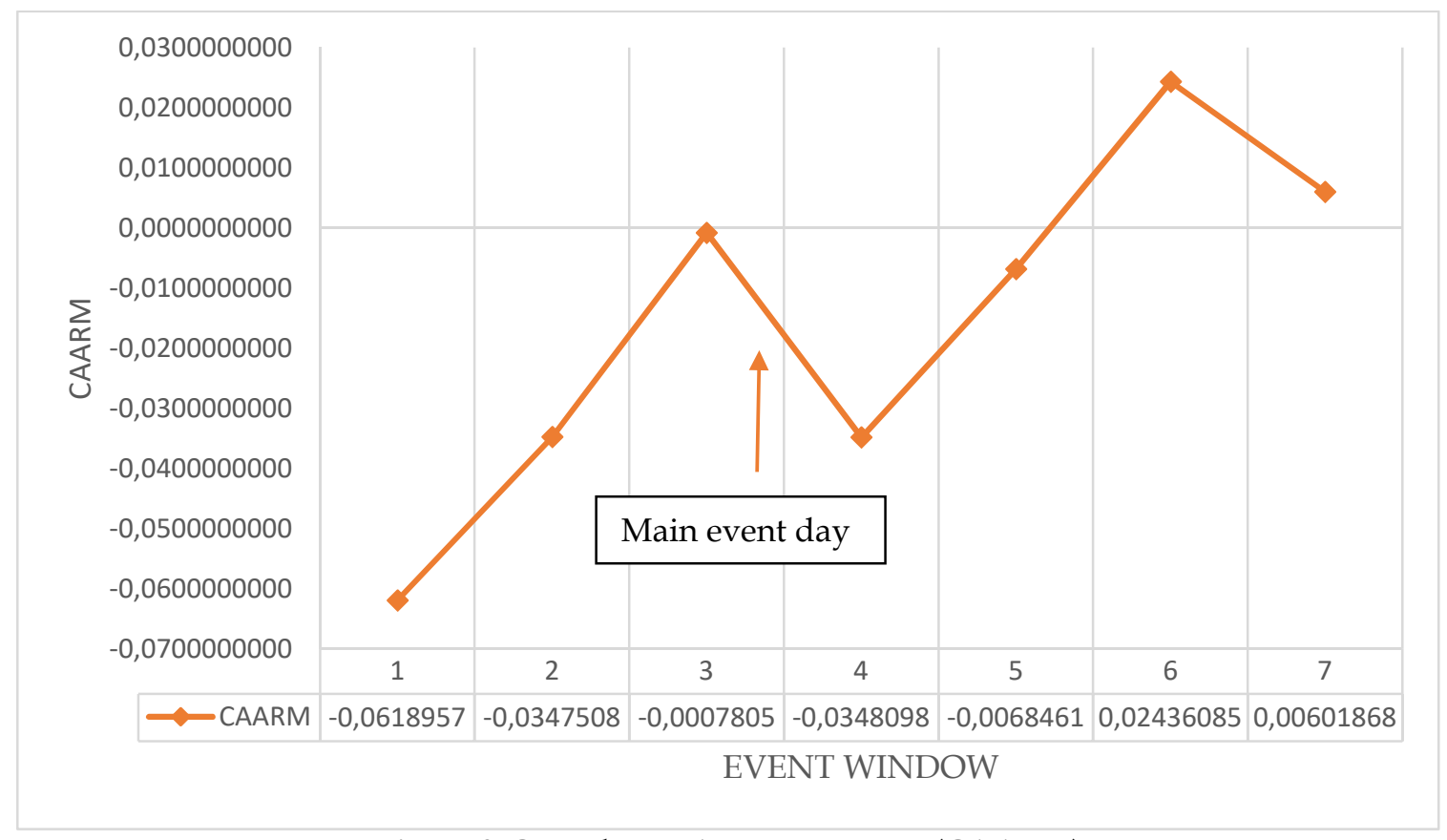

Figure 6. Cumulative Average Return (CAARM)

\section{DISCUSSION}

\section{Statistic Description}

From Table 4 above, it was interesting that only three out of nine industries depicted a reversal direction of return average in the Indonesia Stock Exchange. Those three were Basic and Chemical Industry, Basic Industry, and Finance Industry during the event window $(-20,-1)$. The other six industries did not depict a direction reversal, stayed negative, but it depicted greater values. In this window event, people seemed to start feeling restless over Covid-19 outbreak influences. However, the government had not announced patient cases with Covid-19 since several sports, cultural, and entertainment events were canceled.

After the first announcement of a case with Covid-19 on March 2nd, 2020, every industry exhibited a negative reaction during the event window $(+1,+9)$. However, in the next window event $(+10,+20)$, it appeared that almost every industry (except the finance industry) depicted a negative value of a smaller return average. One industry even scored a positive value which was the mining industry. This described that people were indeed taken aback by the first Covid-19 case announcement for nine trading days. Nonetheless, afterward, people portrayed optimism that Indonesia was able to fight back the Covid-19 outbreak 
Furthermore, in the post-event window $(+21,+53)$ and $(+54,+59)$, optimism was getting more visible for the return average of industry depicted a positive value, except for the Consumer Goods industry. The result of this study was aligned with the study result from Liu et al. (2020) in 21 global stock markets and Sayed and Eledum (2020) in the Arab Saudi stock market.

\section{Cumulative Abnormal Return}

Table 5 depicted the cumulative abnormal return (CAR) of nine industries in the Indonesia Stock Exchange in each window event. The research results shown in Table 5 depicted that there was no cumulative abnormal return before the Covid-19 pandemic (preevent) or in $(-186,-21)$.

Different things were discovered after there were following three window events or in $(-20,-1),(+1,+9)$ and $(+10,+20)$; there were 3 (three) industries that held statistically significant CAR values which were Various Industry, Consumer Goods industry, and Commerce (significance at 5\%). In other words, there was a cumulative abnormal return in those three industries. Not so with the other six industries, which portrayed similar results with a period prior to a pandemic, meaning no cumulative abnormal return.

In the next window event (post-event) or in $(+21,+53)$ and $(+54,+59)$, there 4 (four) industries portraying statistically significant CAR values, which were Consumer Goods industry (significance 1\%), Various Industry (significance 5\%), Infrastructure industry and finance industry (significance 10\%). In other words, there was a cumulative abnormal return in those four industries. Not so with the other five industries that still had no cumulative abnormal return.

Relating to the Covid-19 pandemic effect on Indonesia Stock Exchange, the cumulative average return of the Indonesia Stock Exchange only was affected for the highest short-term in which was in the window event $(+1,+9)$. This was reinforced by Cumulative Average Return (CAARM), which was illustrated in Figure 4. The most affected industry decidedly negatively in this window event was Consumer Goods, while the industry affected extremely positively was the Property industry.

After this event window, the Indonesia Stock Exchange return appeared to experience enforcement in the next window event up to $(+21,+53)$, wherein people were optimistic over the government effort in enforcing the implementation of the new normal scenario by considering the regional promptness and epidemiology research results in related areas.

In the last window event, the Indonesia Stock Exchange return fell back again since the government acted on the enforcement of Commencement for Criteria and Traveling Requirements in accordance with a Circular Letter No. 7, 2020. People seemingly felt back to feel restless in case several business sectors were able to return to normal.

The result of this study was similar to Sayed \& Eledum's (2020), who researched 21 industries in the Arab Saudi stock market wherein it found cumulative abnormal return, which was insignificant to Covid-19 first announcement in Arab Saudi.

\section{CONCLUSIONS AND SUGGESTION}

This study concluded that for the short term, Indonesia Stock Exchange was not overly affected by the Covid-19 pandemic. Cumulative average return drop in Indonesia 
Stock Exchange only then occurred within nine trading days, which were $D+1$ to $D+9$ after the announcement of the first Covid-19 case in Indonesia. The cumulative average return was back to afterward.

Another conclusion is Indonesia Stock Exchange had a cumulative abnormal return in only several industries after the first announcement of the Covid-19 case. Other industries portrayed similar results in pre-event, meaning no cumulative abnormal return. Cumulative abnormal return during an event or in $(-20,-1),(+1,+9)$ and $(+10,+20)$; only appeared in Various Industry sector, Consumer Goods sector and Commerce sector (significance at 5\%). While cumulative abnormal return post-event only appeared in Consumer Goods sector (significance at 1\%), Various Industry sector (significance at 5\%), also Infrastructure sector and Finance sector (significance at 10\%).

Regarding the Covid-19 outbreak that struck worldwide, similar studies are still needed with a longer research duration. This will be strongly helpful to describe the stock exchange reaction in Indonesia and other countries dealing with prolonged Covid-19 outbreak as a valuable resource in the case similar events occurred in the foreseeable future. In Indonesia alone, up to this research was completed, Covid-19 was still taking place and set into the phase of arising Covid-19 patients. It will be highly interesting to be researched further whether the reaction of the Indonesia Stock Exchange will stay the same as the one in 2020 (which was described in this study) or Indonesia Stock Exchange will portray other patterns.

\section{ACKNOWLEDGEMENT}

Thanks to Indonesia Stock Exchange and The Indonesia Capital Market Institute, providing the data related to Indonesia Stock Exchange.

\section{REFERENCES}

Armitage, S. (1995). Event Study Methods and Evidence on Their Performance. Journal of Economic Surveys, 9(1), 25-52. https:/ / doi.org/10.1111/j.1467-6419.1995.tb00109.x

Ayuningtyas, R dan Koesrindartoto, D. (2014). The Relationship between Business Confidence, Consumer Confidence, and Indexes Return Empirical Evidence in Indonesia Stock Exchange. International Conference on Trends in Economics, Humanities, and Management, 21-25. http://dx.doi.org/10.15242/ICEHM.ED0814013

Ball, R dan Brown, P. (1986). An empirical Evaluation of Accounting Income Numbers. Journal of Accounting Research, 6, 159-178. https:/ / doi.org/10.2307/2490232

Chen et al. (2018). Did the S.A.R.S. Epidemic Weaken the Integration of Asian Stock Markets? Evidence From Smooth Time-Varying Cointegration Analysis. Economic Res, 31, 908-926. https://doi.org/10.1080/1331677X.2018.1456354 
Del, A. Giudice dan Paltrinieri, A. (2017). The Impact of the Arab Spring and the Ebola Outbreak on African Equity Mutual Fund Investor Decisions. Res International Business Finance, 41, 600-612. https:/ / doi.org/10.1016/J.RIBAF.2017.05.004

Delattre, E. (2007). Event Study Methodology in Marketing. Research Application in Marketing, 22(2), 57-55.

Donadelli, M et al. (2016). Globally Dangerous Diseases: Bad News for Main Street, Good News for Wall Street?. SAFE Working Paper No. 158, http://dx.doi.org/10.2139/ssrn.2881220

Fama, E., Fisher, L., Jensen, M., dan Roll R. (1969). The Adjustment of Stock Prices to New Information. International Economic Review, 10(1), 1-21. https:// doi.org/10.2307/2525569

Hersugondo, H. dan Karim, A. (2021). Indonesian Capital Market Response Due to Uncertainty Due to the Covid-19 Pandemic. Working paper. February.

Indonesian Stock Exchange. (2021). Produk Indeks. Diambil dari: https://idx.co.id/produk/indeks/. 12 April 2021.

Jakarta's COVID-19 Respons Team (2020). Lini Masa Kebijakan Penanganan Pandemi Covid 19 di Jakarta. Diambil dari: https:/ / corona.jakarta.go.id/en/artikel/linimasakebijakan-penanganan-pandemi-covid-19-di-jakarta. 15 April 2021.

Komite Penanganan Covid 19 dan Pemulihan Ekonomi Nasional. (2002). Peta Sebaran Covid-19. Diambil dari: https:// covid19.go.id/peta-sebaran. 10 Mei 2021.

Liu, H et al. (2020). The Covid-19 Outbreak and Affected Countries Stock Markets Response. International Journal of Environmental Research and Public Health, 17(8), 2800. https://doi.org/10.3390/ijerph17082800

Liu, H et al. (2020). Short Term Response of Chinese Stock Markets to The Outbreak of Covid-19. Applied Economics, 52(53), 1-14. https:// doi.org/10.1080/00036846.2020.1776837

Macciocchi et al. (2016). Short-term Economic Impact of the Zika Virus Outbreak. New Microbiol, 39, 287-289.

MacKinlay, A. (1997). Event Studies in Economics and Finance. Journal of Economic Literature, 35(1), 13-39. https://www.jstor.org/stable/2729691

Nia, V. M. (2020). The Effect of Corona Outbreak on the Indonesian Stock Market. American Journal of Humanities and Social Sciences Research (AJHSSR), 4(3), 358-370.

Pendell, D. dan Cho, C. (2013). Stock Market Reactions to Contagious Animal Disease Outbreaks: An Event Study in Korean Foot-and-Mouth Disease Outbreaks. Agribusiness, 29(4), 455-468. https://doi.org/10.1002/agr.21346 
Sayed, O., dan Eledum, H. (2020). The Short-run Response of Saudi Arabia Stock Market to the Outbreak of COVID-19 Pandemic: An Event-study Methodology. International Journal of Finance Economy, 2(1), 1-15. https:/ / doi.org/10.1002/ijfe.2539

Schell, D et al. (2020). This Time is Indeed Different: A Study on Global Market Reactions to Public Health Crisis. Journal of Behavioral and Experimental Finance, 27, 100.349. https:/ / doi.org/10.1016/j.jbef.2020.100349

Selmi, R., \& Bouoiyour, J. (2020) Global Market's Diagnosis on Coronavirus: A Tug of War between Hope and Fear. https:/ / hal.archives-ouvertes.fr/hal-02514428

Yudhistira, Aria W. (2020). Covid-19 Menjatuhkan Ekonomi Asia Tenggara. Diambil dari: https:/ / katadata.co.id/ariayudhistira/infografik/5f45ee727502e/covid-19menjatuhkan-ekonomi-asia-tenggara. 22 April 2021.

Wang, Y et al. (2013). An Investor's Perspective on Infectious Diseases and Their Influence on Market Behaviour. Journal of Business Economics and Management, 14(1), 112127. https:// doi.org/10.3846/16111699.2012.711360

World Health Organization. (2020). Archived: WHO Timeline - COVID-19. https://www.who.int/news/item/29-06-2020-covidtimeline._April 5th, 2021

World Health Organization. (2020). International Publication. https://www.who.int/publications/m/item/weekly-epidemiological-update-oncovid-19---20-april-2021. April 5th, 2021.

World Health Organization. (2020). Visual Summary on Covid-19. https://www.who.int/data/gho/whs-2020-visual-summary. May 5th, 2021. 